\title{
AGRICULTURAL CAPABILITY AND SUITABILITY OF WADI EL-FARIGH, WESTERN DESERT OF EGYPT
}

\author{
Mohamad Ahmad Al Howeity ${ }^{1}$, Waleed. M. Darwisch ${ }^{2}$, Shaymaa Atef Al-SAyed ${ }^{3}$
}

Department Evaluation of Natural Resources and Planning its Projects EnvironmentalDepartment Studies and Research Institute - University of Sadat City

\section{ABSTRACT}

$\mathrm{t}$ he agricultural expansion in the desert areas is one of the main objects of the national plan to meet the food requirement for the tremendous increase in population. This research work presents an approach to analyze the enormous complexity of land resources and its use and management from an agro-ecological perspective. It discusses the efficiency of land evaluation for assessing land use changes in rural areas. Wadi El Farigh in the Western Desert of Egypt, was selected as a case study. Fourteen representative soil profiles had been selected to assess the soil variation and validation for agricultural prospective of the study area. The soils of the study area were related to Entisols and were classified under subgroups Lithic Torripsamments and Typic Torripsamments. By using the GIS technique, the unsupervised and supervised method was carried out to separate the cultivated and the barren soils. Based on these classes, the obtained data were summarized. Agricultural soil capability indices have been calculated for the study area according to Storie index. Accordingly, three classes were identified, namely fair, poor and non-agricultural soils where the soil texture is the main limiting factor. On the other hand, Agricultural soil suitability indices had been calculated according to Land Use Suitability Evaluation Tool (LUSET). The obtained results revealed that the soil suitability showed that major suitability classes have been noted are , moderately suitable (S2) for all the selected crops with some exceptional cases that are highly suitable (S1) or (S3) that are marginally suitable for all selected crops, Table (6 and 7). The areas that were represented by the soil profiles Nos.1 and 2 were moderately suitable for the Cucumber, Watermelon, Onion, Green Pepper, Sunflower, Potato, Barley, Wheat, Sorghum, Maize, Olive, Sesame and Mango. On the other hand, they are marginally suitable for Pear. The areas that are represented by the soil profiles Nos. 3 to 10 are moderately suitable for the Cucumber, Watermelon, Onion, Green Pepper, Sunflower, Potato, Groundnut, Pear, Wheat, Maize, Olive, Sesame and Mango. On contrary, they were highly suitable for Barley and Sorghum. Soil texture was the most limiting factor for all soils, units in addition to soil depth especially for the soils of profiles Nos. 1 and 2.

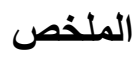

يعتبر التوسع الزر اعي في المناطق الصحر اوية أحد أهم عناصر الخطة الوطنية لتلبية الاحتياجات الغذائية للزيادة الهائلة

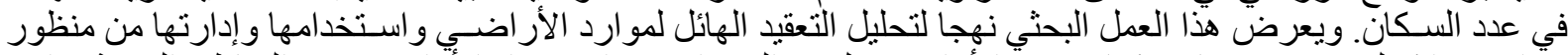

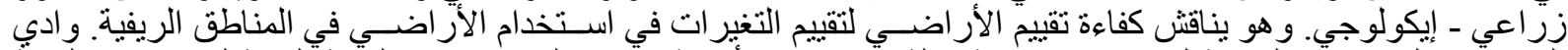

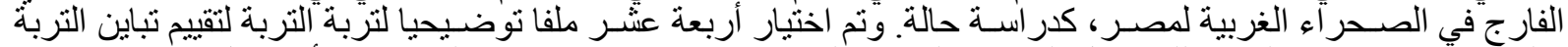

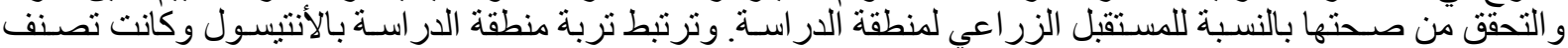

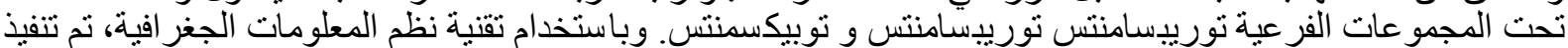

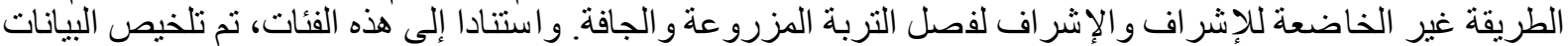

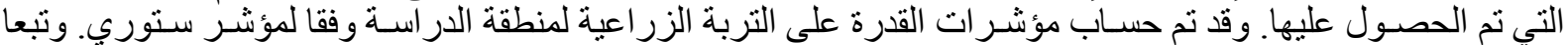

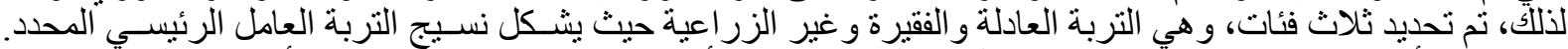

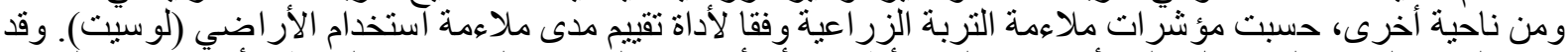

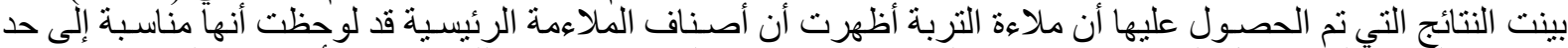

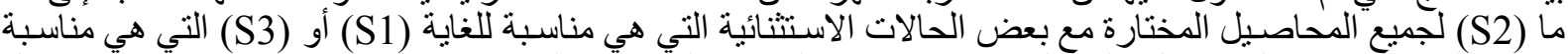

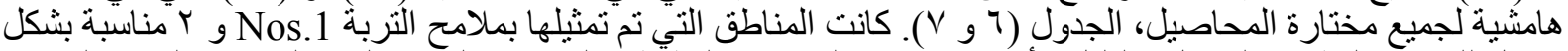

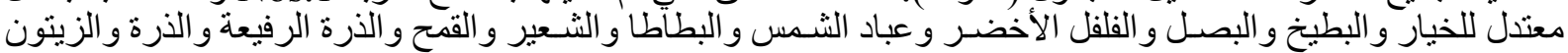




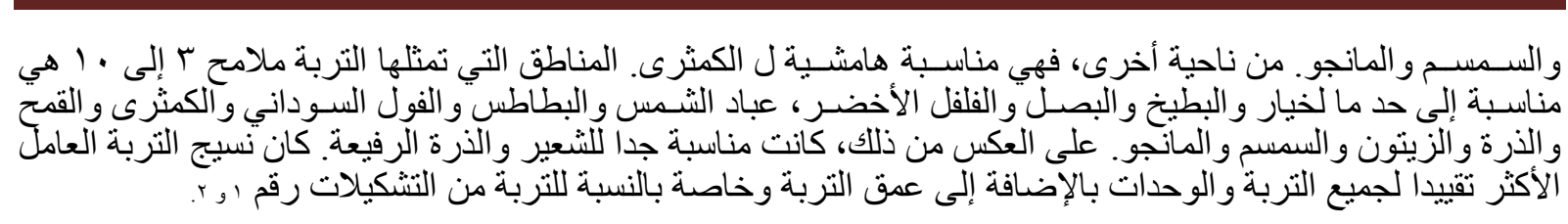

\section{1- INTRODUCTION}

Nowadays, great attention is paid by the Egyptian Authorities for the establishment of new settlements and land reclamation projects to overcome the overpopulation

problem. To overcome the problem and narrow the gap that exist between food production and consumption, Egyptian authorities adopted policies aiming at self-sufficiency in food production. This accomplished by horizontal extension of cultivated areas. This fact necessitates an essential demand for evaluating and classifying the soil according to its agricultural productivity. A modern nation, as a modern business, must have adequate information on many complex interrelated aspects of their activities in order to make decisions. Land use is the only one such aspect, but knowledge about land use and land cover has become increasingly important as the national plans to overcome the problems of hazard, uncontrolled development, deteriorating environmental quality, loss of prime agricultural lands, destruction of important wetlands, and loss of fish and wildlife habitat, Anderson et al. (2001). Land use data are needed in the analysis of environmental processes and problems that must be understood if living conditions and standards are to be improved or maintained at current level.

Inappropriate land use leads to inefficient exploitation of natural resources, destruction of the land resources, poverty and other social problems, Rossiter (1996). Land evaluation is defined as the process of land performance assessment when the land is used for specific purposes, (FAO, 1985) or as all methods to explain or predict the use potential of land, Van Diepen et al., (1991). Information about soil and site properties is the raw materials for indicating land evaluation. These are often considered as land characteristics which can be directly observed or assessed. Indirect land evaluation normally uses a combination of soil characteristics and qualities, Beek (1978). Land evaluation includes qualitative and quantitative systems. Land may be evaluated directly by endeavors that are by growing crops. Direct evaluation is limited value unless the evaluator has the resources to collect a large amount of information, Olsen (1981) . Those most land evaluation systems are indirect. They suppose that certain soil and site properties influence the success of a particular land use in a reasonably predictable manner, and that the quality of land can be concluded from observation of those properties, Vink (1983). The first endeavor for rating the soil attributes was carried out by Storie (1932) whereas the soil attributes were categorized into three factors. It was revised and modified by, Olsen (1974). whereas the equation was recognized by the land productivity index. The latest modification of the Storie Index was published in 1978, which was also revised by UCDAVIS (2008) using the same concept for getting the index rating. With represent to this modification. FAO (1981) designed a framework for land evaluation to serve practical purposes. This framework aims to attain three basic principles, they are, i) land suitability is assessed and classified with respect to specific kinds of use, whereas each kind of use has own land requirements, ii) evaluation requires a comparison of the benefits obtained and the inputs required for different types of land, and iii) a multidisciplinary approach is required. Sys and Verheye (1978) made an attempt to evaluate the physical land characteristics for irrigation based on the framework for land evaluation. The detailed of this system will be illustrated later. Sys (1980) designed methods for rating the land characteristics and qualities, whereas the land characteristics are measurable properties of the physical environment related to land use. Computers have been applied to land evaluation at different level of detail. One of these computer programs is called Mediterranean Land Evaluation Information System (MicroLEIS), De La Rosa et al. (1992) for land evaluation in Mediterranean climates. This program includes a series of computerized models used for agro-ecological evaluation. They are based on productivity related aspects. Recently, the International Rice Research Institute developed a new computer program called Land Use Suitability Evaluation Tool (LUSET), Yen et al. (2006). This program is based on the criteria 
of FAO (1981) Framework and Sys et al. (1991). In this respect, the southwestern fringes of the Nile Delta constitute a promising area for land reclamation due to its favorable soil, availability of groundwater and accessibility to Cairo, Alexandria, Central Delta and the northwestern coast. So the area under consideration, Wadi El- Farigh, attracts the attention of several investments in the field of land reclamation. In this area several water wells were drilled for groundwater exploration and exploitation for the construction farms. Accordingly, it is recently subjected to intensive studies in the field of geology, pedology and hydrology.

Hence the studies which related to the groundwater potentialities of Wadi El Farigh proved that the quality and quantity of groundwater are fair enough establishing the agricultural projects including field crops, fruit, and vegetables. So the present study aims at asses the land capability and land suitability of Wadi El-Farigh soils based on their physical and chemical characteristics.

\section{2- MATERIALS AND METHODS}

\subsection{GENERAL OCCURRENCE AND FEATURES}

The investigated area, Wadi El-Farigh, lies to the southwestern portion of the Nile Delta occupying a small part of the northern Western Desert. It is bounded by Cairo Alexandria highway from its east portion and extended westward to the western extreme of Wadi El Farigh basin. On the other hand, it is bounded from the north by Wadi El Natrun. The area is bounded by Latitudes $29^{\circ} 59^{\prime} 59.96^{\prime \prime} \mathrm{N}$ to $30^{\circ} 13^{\prime} 08.57^{\prime \prime} \mathrm{N}$ and Longitudes $30^{\circ} 24^{\prime} 57.14^{\prime \prime} \mathrm{E}$ to $30^{\circ} 58^{\prime}$ $02.28^{\prime \prime}$ E, (Fig. 1). The area of study occupies a desert portion of Egypt with extremely arid climatic conditions, while in the northern portions of the study area arid climatic conditions are prevailing. The prevailing climate is characterized by long hot summer, short worm winter, low rainfall and high evaporation intensities. The average minimum air temperature is recorded during February and it varies from $4.7^{\circ} \mathrm{C}$ (Maryuit station) to $8.5^{\circ} \mathrm{C}$ (Ganakles station), while the maximum air temperature is recorded in July, where it varies from $40.2^{\circ} \mathrm{C}$ (Giza station) to $33.5^{\circ} \mathrm{C}$ (Ganakles station), Egyptian Meteorological Authority (2006). The mean annual rainfall ranges between $13.8 \mathrm{~mm} /$ year (Maryuit station) and $18.3 \mathrm{~mm} /$ year (West Cairo station). The maximum rainfall value is recorded at January, February, March, November and December, while the minimum values were recorded in June, July and August. The evaporation intensity indicated that the average values of evaporation vary from $1.73 \mathrm{~mm} /$ day in January (winter) at Maryuit station to $17 \mathrm{~mm} /$ day in July (summer) at Cairo station. The relative humidity is generally higher in winter than in summer. The maximum and minimum relative humidity values are recorded in January and May respectively. It varies from $75.02 \%$ at Maryuit station to $44.2 \%$ at Wadi El Natrun station. The degree of aridity is determined by using the Emberger formula (1955) indicated that the desert condition is prevailing within the study area under consideration. As for the geological setting, the geological map established by El Abd (2005) indicated that the geological structure of Wadi El-Farigh is mainly placed in early Pleistocene age, late Pleistocene age and Quaternary age. The current study is depending on the recent study related to the geomorphic setting carried out by El Abd (2005) to recognize the main geomorphic unit covered Wadi El-Farigh. Accordingly Wadi El-Farigh is representing mainly by structural depression as a landform. Structural depressions constitute one of the main land features in the study area. As for the water resources. Groundwater is considered the mainly source of water for irrigation in the study area. Concerning the Miocene groundwater, the total salinities reflect that, the groundwater is mainly suitable for agriculture (TDS ranges from 179.45 to $286.25 \mathrm{mg} / \mathrm{l}$ ) with exceptional cases where the groundwater salinity is over than $3000 \mathrm{mg} / \mathrm{l}$, El Abd (2005).

\subsection{SOIL SAMPLING AND LABORATORY ANALYSIS}


Two different types of digital data were used in the present study. Landsat Thematic Mapper, ETM8, path 177 row 39, (Fig. 2) acquired on March 19th, 2013, Digital Elevation Model, EM30m, (Fig. 3), acquired on June 26th, 2003, were provided by U.S Geological Survey Website accessed in 2015. The DEM was used to create and the general slope dominated through the study area, (Fig. 4). Based on the Landsat data of the study area was supervisory classified.

Ground truth followed in this work was done by selecting several sampling sites for representing the two units which are the barren soils and cultivated soils. Accordingly, fourteen soil profiles were dug to $150 \mathrm{~cm}$ depth unless hindered by bedrock or water table. These soil profiles were pedo-morphologically described according FAO (2006). The exact location of the soil profiles (14) were precisely defined in the field using the Global Positioning System (GPS; Garmin Montana 650) and plotted on maps (Figs.3\&4) Based on the pedo-morphological description, 40 soil samples were collected for the laboratory analyses. The collected soil samples were dried, crashed and sieved through a 2-mm sieve. The coarse size; gravels and stones, was determined volumetrically (Soil Survey Staff, 2004), while the fine size was taken and kept for physical, chemical, fertility analyses.

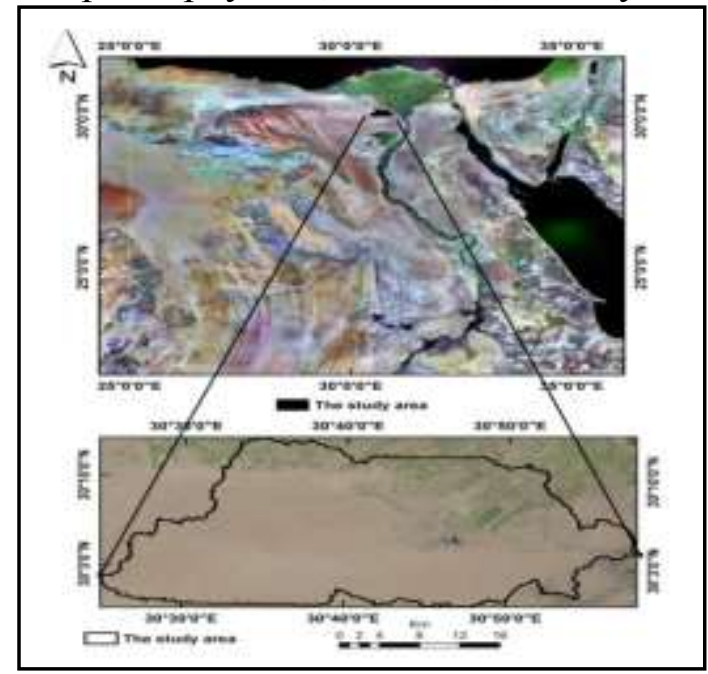

Fig. 1: Location of the study area.

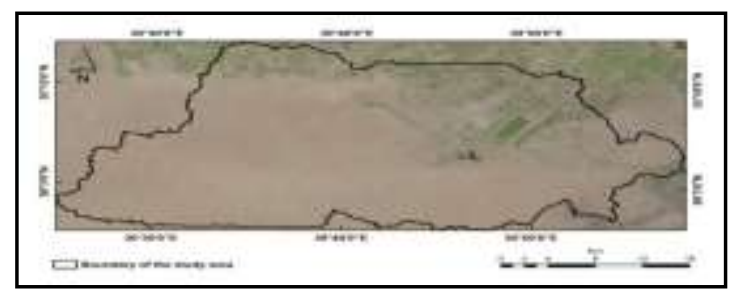

Fig. 2: Landsat Thematic Mapper, ETM8, path 177 row 39 of the study area

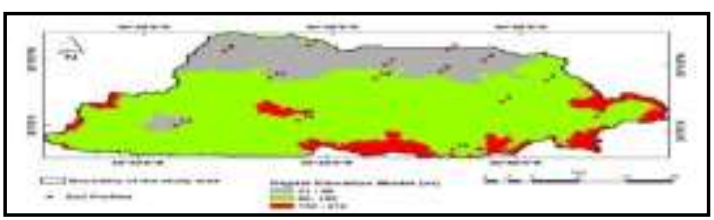

Fig. 3: Digital Elevation Model, DEM$30 \mathrm{~m}$,of the study area

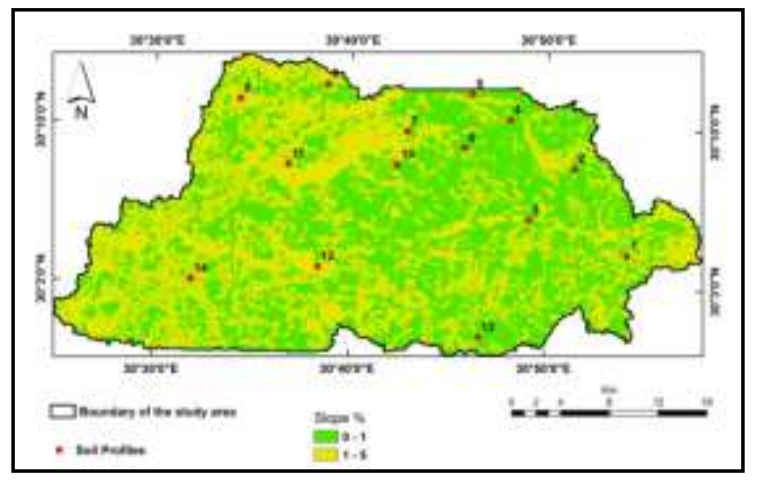

Fig. 4: Surface slope of the study area

The routine analyses including soil $\mathrm{pH}$, electrical conductivity, soluble cations and anions were estimated in the soil paste extract, (Bashour and Sayegh, 2007). Calcium, magnesium, chloride, carbonate, and bicarbonate were determined titrimetrically. Potassium and sodium was determined photo-metrically using Flame photometer. Finally, the sulfate was calculated by subtracting the total soluble anions from the total soluble cations. The total calcium carbonate was measured by treating the samples with $\mathrm{HCl}$ and the evolved $\mathrm{CO}_{2}$ was measured manometrically, (Soil Survey Staff, 2004.). The organic matter content was estimated using 
Walkley and Balk titration method, (Bashour and Sayegh, 2007). The particle size distribution (size $<2 \mathrm{~mm}$ ) was carried out by using dry sieving, Piper (1950).

\section{2-3- SOIL AND LAND CLASSIFICATION}

Based on the field examination and laboratory analyses, soil classification was carried out to the sub group level using Key of soil taxonomy, Soil Survey Staff (2014). Two systems for land evaluation were carried out through two steps. First evaluate the Land capability classification by using Modified Storie Index Rating, UCDVIS (2008): The calculation was run and coding using Visual Basic for application under Microsoft Excel created by Aldabaa (2012). Second, evaluate the Land suitability classification by using Land Use Suitability Evaluation Tool (LUSET), Yen et al. (2006) a computer- based program.

\section{3- RESULTS AND DISCUSSIONS}

\section{3-1- THE SOIL PROPERTIES OF THE STUDY AREA}

The area of the study occupies an area of about 200350 feddan. Based on the unsupervised and supervised maps the area is divided into two types of soils, namely cultivated soils and barren soils. The cultivated soils represented $28.35 \%$ of the total area, and the barren soils represented $71.65 \%$ (Fig. 5). The characteristics of each soil unite will be discussed as follow:

\section{3-1-1- CULTIVATED SOILS:}

This unit occupies approximately 58500 feddan, the soils of this unit are represented by 10 soil profiles (1 to 10). It is a cultivated area planted mainly with the following:

- Perennials: Mango, Olives, Orange and Grapes.

- Annuals: Alfalfa.

- Seasonal: Tomato, Eggplant, and Onion.

The topography of this unite is almost flat with leveled slop, except the areas that are represented by soil profiles 1and 3 where the topography is gently undulating with gently sloping and nearly level respectively, and the surface is covered by residual plant leaves and shoots and scattered varisized rock fragments. Some pedological features have been detected in this unit such as, many fine to medium roots, many partially decomposed organic matter, and many fine to coarse rock fragments. The soils are generally deep where the effective depth is ranging from 100 to $150 \mathrm{~cm}$. except the areas that are represented by soil profiles, 1 and 2 are very shallow and the depth almost $20 \mathrm{~cm}$. Soil profiles, no. 8 and 10 are bounded by very consolidated layer .Physically, the soil texture of the study area is course textured (coarse to medium sand) while the structure and consistency are massive and soft. The gravel content is fluctuated between 0 to $24.05 \%$. The high value of gravel is found in soil profiles no.5 and 7 , and the gravels are accumulated on the surface. Calcium carbonate varies from 0.15 to $8.3 \%$ with remarkable increasing in the subsurface layers (Table 1). The chemical data, which are displayed in table 2 , show that soils of this unit are generally free saline soils $(<2 \mathrm{dS} / \mathrm{m})$, except areas that are represented by profiles numbers. 5,6,7,8 the soils are slightly to moderately saline or saline $(2-8 \mathrm{dS} / \mathrm{m})$. The dominant cation is sodium followed by calcium then magnesium and the least dominant is potassium where as the dominant anion is chloride followed by sulphate then bicarbonate. The soil reaction is ranging from neutral to slightly alkaline (6.93-7.6) with few exceptions where the soil reaction is moderately alkaline (7.8-8.4) such as surface layers of the area that represented by profile no. 3 and subsurface and deepest layers of the area that is represented by profile no. 5 .

The fertility status, which is shown table (1), revel that the organic matter content is ranging from 0.52 and $2.14 \%$ and show accumulation on the surface because these soils are cultivated. In general, the low value of organic matter is due to the hyperthermic temperature dominating in the study area. This type of condition leads to accelerate the mineralization processes leading to decrease the organic matter content. The available nitrogen is marginal whereas its values ranged from 30 to $76 \mathrm{mg} / \mathrm{kg}$ except areas that are represented by profile no. 1 where it increases to reach $102 \mathrm{mg} / \mathrm{kg}$. The soils are poor in phosphorus (less than $14 \mathrm{mg} / \mathrm{kg}$ ) except areas that are 
represented by profiles numbers. $1,2,3,6$, and 9, where it increases to range from $18.6-32.2$ $\mathrm{mg} / \mathrm{kg}$, while they have no adequate content of potassium $(<120 \mathrm{ppm})$ except areas that represented by profiles numbers. 1, 6, 8, 9 where its content is ranging from 121 to $762 \mathrm{ppm}$.

\section{3-1-2- BARREN SOILS}

This unite occupies approximately 141,850 feddan, the soils of this unit are represented by 4 soil profiles (11 to 14). The topography of this unite is flat with level slop, and the surface is covered by sand sheet.

The soils are generally deep where the effective depth is $150 \mathrm{~cm}$. Soil profiles no. 8 and 10 are bounded by much consolidated layer. Physically, the soils are of course texture (course to medium sand) and the surface layers are the coarser, while the structure and consistency are massive and soft. The gravel content is almost $22.5 \%$, it is only occurred on the surface layers. The soils of this unit are slightly calcareous as the calcium carbonate $<2$, (Table,3). The chemical data, which are displayed in table 4, show that soils of this unit are generally free saline soils $(<2 \mathrm{dS} / \mathrm{m})$. 
Journal of Environmental Studies and Researches (2017), 6(E2): 280-294

\begin{tabular}{|c|c|c|c|c|c|c|c|c|c|c|c|}
\hline \multirow{3}{*}{ Profile No. } & \multicolumn{11}{|c|}{ able 1: Some Physical properties and Fertility status of Wadi El Farigh, (Cultivated soils). } \\
\hline & Depth & Gravel & \multicolumn{3}{|c|}{ Particle Size Distribution \% } & \multirow[t]{2}{*}{ Texture } & \multicolumn{3}{|c|}{ Fertility status(mg/kg) } & \multirow{2}{*}{$\frac{\%}{\mathrm{O} . \mathrm{M}}$} & \multirow[t]{2}{*}{$\mathrm{CaCO}_{3} \%$} \\
\hline & $\mathrm{Cm}$ & $\%$ & C.S & M.S & F.S & & $\mathrm{N}$ & $\mathrm{P}$ & $\mathrm{K}$ & & \\
\hline 1 & $0-20$ & 18.72 & 16.00 & 38.00 & 46.00 & M.S & 102 & 18.6 & 762 & 2.14 & 5.51 \\
\hline 2 & $0-20$ & 17.82 & 17.00 & 39.50 & 43.50 & M.S & 76 & 23.83 & 93.8 & 1.34 & 5.53 \\
\hline \multirow[t]{3}{*}{3} & $0-50$ & 11.00 & 45.50 & 23.5 & 31.00 & C.S & 64.0 & 22.42 & 76.2 & 1.14 & 1.71 \\
\hline & $50-100$ & 5.55 & 34.00 & 42.00 & 24.00 & C.S & & & & & 0.12 \\
\hline & $100-150$ & 3.27 & 28.50 & 29.00 & 42.50 & C.S & & & & & 0.15 \\
\hline \multirow[t]{3}{*}{4} & $0-45$ & 7.84 & 35.22 & 37.78 & 27.00 & C.S & 57.6 & 5.58 & 115.6 & 0.76 & 3.30 \\
\hline & $45-100$ & 3.85 & 40.50 & 50.00 & 9.50 & C.S & & & & & 1.00 \\
\hline & $100-150$ & 6.98 & 54.55 & 35.00 & 11.00 & C.S & & & & & 1.50 \\
\hline \multirow[t]{3}{*}{5} & $0-50$ & 24.05 & 30.00 & 43.50 & 26.50 & C.S & 30.0 & 2.12 & 34.0 & 0.49 & 2.54 \\
\hline & $50-90$ & 0.00 & 16.00 & 38.00 & 46.00 & M.S & & & & & 1.23 \\
\hline & $90-150$ & 0.00 & 3.00 & 54.00 & 43.00 & M.S & & & & & 1.28 \\
\hline \multirow[t]{3}{*}{6} & $0-40$ & 6.12 & 17.50 & 38.00 & 44.50 & M.S & 41.8 & 29.25 & 136.0 & 0.65 & 2.70 \\
\hline & $40-80$ & 11.11 & 28.50 & 29.00 & 42.50 & C.S & & & & & 3.50 \\
\hline & $80-150$ & 4.37 & 16.00 & 38.00 & 46.00 & M.S & & & & & 0.90 \\
\hline \multirow[t]{5}{*}{7} & $0-20$ & 17.07 & 23.00 & 32.00 & 45.00 & M.S & 48.0 & 2.19 & 62.6 & 0.49 & 8.30 \\
\hline & $20-40$ & 5.71 & 15.50 & 39.00 & 45.50 & M.S & 36.0 & 2.97 & 80.2 & 0.42 & 3.00 \\
\hline & $40-60$ & 4.91 & 27.00 & 37.50 & 35.50 & C.S & & & & & 2.70 \\
\hline & $60-110$ & 3.15 & 17.00 & 39.50 & 43.50 & M.S & & & & & 2.20 \\
\hline & $110-150$ & 6.69 & 34.00 & 42.00 & 24.00 & C.S & & & & & 1.50 \\
\hline \multirow[t]{3}{*}{8} & $0-30$ & 0.00 & 45.50 & 23.5 & 31.00 & C.S & 30.0 & 2.02 & 36.7 & 0.61 & 1.50 \\
\hline & $30-60$ & 0.00 & 47.00 & 22.50 & 30.50 & C.S & 53.6 & 7.18 & 121.0 & 0.94 & 3.10 \\
\hline & $60-120$ & 0.00 & 57.00 & 17.50 & 25.50 & C.S & & & & & 1.40 \\
\hline \multirow[t]{3}{*}{9} & $0-40$ & 6.18 & 17.50 & 38.00 & 44.50 & M.S & 50.4 & 32.44 & 354.0 & 1.52 & 2.75 \\
\hline & $40-80$ & 11.221 & 28.50 & 29.00 & 42.50 & C.S & & & & & 3.55 \\
\hline & $80-150$ & 4.39 & 16.00 & 38.00 & 46.00 & M.S & & & & & 1.05 \\
\hline \multirow[t]{2}{*}{10} & $0-30$ & 0.00 & 45.50 & 23.5 & 31.00 & C.S & 36.0 & 2.28 & 51.7 & 0.71 & 1.55 \\
\hline & $30-60$ & 0.00 & 47.00 & 22.50 & 30.50 & C.S & 40.8 & 3.86 & 65.3 & 0.59 & 3.18 \\
\hline
\end{tabular}




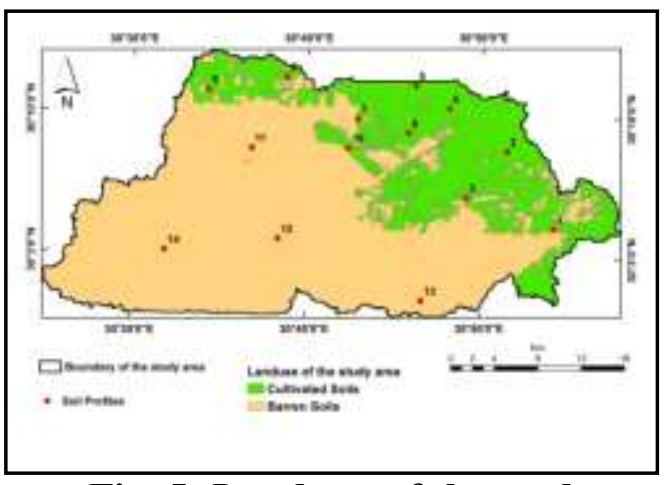

Fig. 5: Land use of the study area

Table 2: Some chemical properties of Wadi EI Farigh, (Cultivated soils).

\begin{tabular}{|c|c|c|c|c|c|c|c|c|c|c|c|}
\hline \multirow[t]{2}{*}{ profile } & Depth & \multirow[t]{2}{*}{$\mathrm{pH}$} & $\mathrm{EC}$ & \multicolumn{4}{|c|}{ Soluble Cations me/l } & \multicolumn{4}{|c|}{ Soluble anion me/l } \\
\hline & $\mathrm{Cm}$ & & $\mathrm{dS} / \mathrm{m}$ & $\mathrm{Ca}^{++}$ & $\mathrm{Mg}^{++}$ & $\mathrm{Na}^{+}$ & $\mathrm{K}^{+}$ & $\mathrm{CO}_{3}^{--}$ & $\mathrm{HCO}_{3}^{-}$ & $\mathrm{Cl}^{-}$ & $\mathrm{SO}_{4}^{--}$ \\
\hline 1 & $0-20$ & 7.50 & 3.67 & 2.50 & 1.56 & 31.09 & 0.39 & 0.00 & 1.56 & 31.62 & 2.37 \\
\hline 2 & $0-20$ & 7.40 & 3.66 & 7.94 & 4.91 & 22.79 & 1.01 & 0.00 & 3.43 & 24.30 & 8.91 \\
\hline \multirow[t]{3}{*}{3} & $0-50$ & 7.90 & 0.13 & 1.45 & 0.95 & 2.41 & 0.47 & 0.00 & 0.97 & 3.16 & 0.68 \\
\hline & $50-100$ & 7.7 & 0.18 & 1.44 & 0.96 & 2.40 & 0.48 & 0.00 & 0.96 & 3.17 & 0.68 \\
\hline & $100-150$ & 7.8 & 0.18 & 1.46 & 0.94 & 2.42 & 0.46 & 0.00 & 0.98 & 3.15 & 0.68 \\
\hline \multirow[t]{3}{*}{4} & $0-45$ & 7.10 & 0.56 & 0.98 & 0.59 & 3.82 & 0.21 & 0.00 & 1.20 & 3.92 & 0.48 \\
\hline & $45-100$ & 7.09 & 1.38 & 3.50 & 2.45 & 7.57 & 0.23 & 0.00 & 2.45 & 7.95 & 3.34 \\
\hline & $100-150$ & 6.98 & 1.15 & 2.25 & 1.47 & 7.29 & 0.56 & 0.00 & 1.96 & 7.40 & 2.23 \\
\hline \multirow[t]{3}{*}{5} & $0-50$ & 7.33 & 5.67 & 7.35 & 5.39 & 33.55 & 0.94 & 0.00 & 3.92 & 34.47 & 8.57 \\
\hline & $50-90$ & 8.22 & 1.29 & 1.16 & 0.76 & 3.58 & 0.25 & 0.00 & 1.21 & 3.65 & 0.75 \\
\hline & $90-150$ & 8.07 & 0.57 & 1.16 & 0.76 & 3.58 & 0.25 & 0.00 & 1.21 & 3.65 & 0.75 \\
\hline \multirow[t]{3}{*}{6} & $0-40$ & 6.93 & 2.65 & 4.59 & 3.39 & 16.50 & 1.02 & 0.00 & 2.49 & 17.70 & 5.30 \\
\hline & $40-80$ & 6.98 & 2.60 & 4.67 & 2.92 & 18.07 & 0.62 & 0.00 & 1.72 & 18.49 & 6.08 \\
\hline & $80-150$ & 7.09 & 1.76 & 2.47 & 1.75 & 12.15 & 0.75 & 0.00 & 0.85 & 12.93 & 3.52 \\
\hline 7 & $0-20$ & 6.97 & 2.33 & 4.24 & 2.76 & 15.21 & 0.91 & 0.00 & 1.38 & 16.59 & 5.25 \\
\hline
\end{tabular}


Shaymaa Atef Al-SAyed et al.

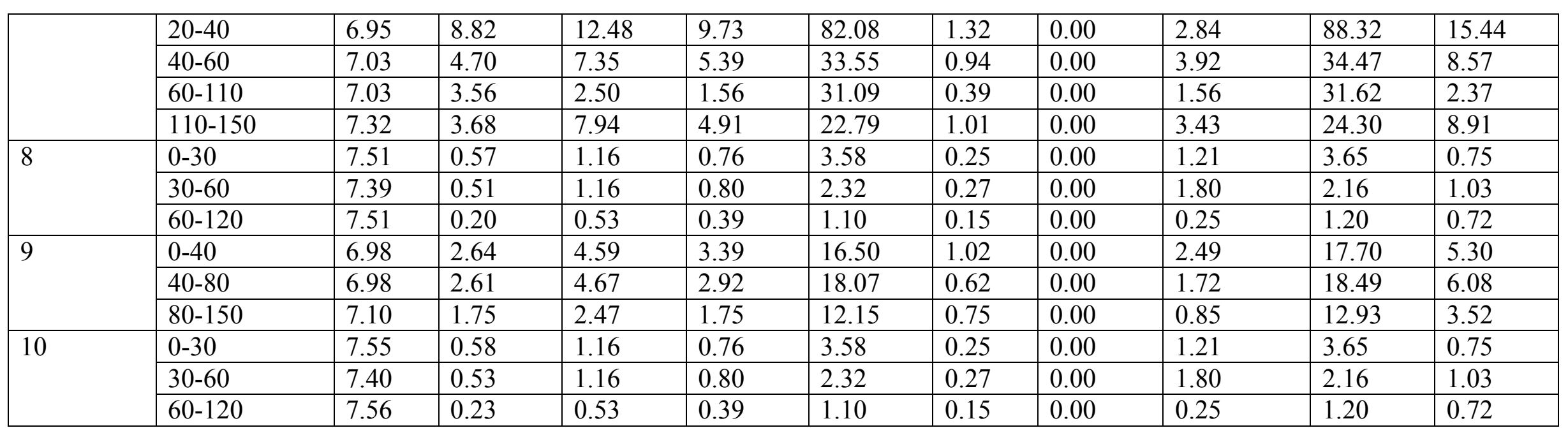

Table 3: Some Physical properties and Fertility status of Wadi El Farigh, (Barren area).

\begin{tabular}{|c|c|c|c|c|c|c|c|c|c|c|c|}
\hline \multirow[b]{2}{*}{ Profile } & \multirow{2}{*}{$\begin{array}{c}\text { Depth } \\
\mathrm{Cm}\end{array}$} & \multirow{2}{*}{$\begin{array}{c}\text { Gravel } \\
\%\end{array}$} & \multicolumn{3}{|c|}{ Particle Size Distribution \% } & \multirow[t]{2}{*}{ Texture } & \multicolumn{3}{|c|}{ Fertility Status (mg/kg) } & \multirow{2}{*}{$\begin{array}{c}\% \\
\text { O.M }\end{array}$} & \multirow{2}{*}{$\begin{array}{r}\mathrm{CaCO}_{3} \\
\\
\end{array}$} \\
\hline & & & C.S & M.S & F.S & & $\mathrm{N}$ & $\mathrm{P}$ & $\mathrm{K}$ & & \\
\hline \multirow[t]{3}{*}{11} & $0-50$ & 22.45 & 30.00 & 43.50 & 26.50 & C.S & 30.0 & 2.12 & 34.0 & 0.49 & 1.60 \\
\hline & $50-100$ & 0.00 & 6.50 & 64.50 & 29.00 & M.S & & & & & 1.00 \\
\hline & $100-150$ & 0.00 & 3.00 & 54.00 & 43.00 & M.S & & & & & 1.00 \\
\hline \multirow[t]{3}{*}{12} & $0-50$ & 22.55 & 30.00 & 43.50 & 26.50 & C.S & 30.0 & 2.02 & 36.7 & 0.61 & 1.68 \\
\hline & $50-100$ & 0.00 & 6.50 & 64.50 & 29.00 & M.S & & & & & 1.20 \\
\hline & $100-150$ & 0.00 & 3.00 & 54.00 & 43.00 & M.S & & & & & 1.80 \\
\hline \multirow[t]{3}{*}{13} & $0-50$ & 22.25 & 30.00 & 43.50 & 26.50 & C.S & 36.0 & 2.97 & 80.2 & 0.42 & 1.90 \\
\hline & $50-100$ & 0.00 & 6.50 & 64.50 & 29.00 & M.S & & & & & 1.09 \\
\hline & $100-150$ & 0.00 & 3.00 & 54.00 & 43.00 & M.S & & & & & 1.50 \\
\hline \multirow[t]{3}{*}{14} & $0-50$ & 22.35 & 30.00 & 43.50 & 26.50 & C.S & 31.0 & 2.11 & 34.50 & 0.48 & 1.70 \\
\hline & $50-100$ & 0.00 & 6.50 & 64.50 & 29.00 & M.S & & & & & 1.80 \\
\hline & $100-150$ & 0.00 & 3.00 & 54.00 & 43.00 & M.S & & & & & 1.90 \\
\hline
\end{tabular}


Table 4: Some Chemical properties of Wadi El Farigh, (Barren soils).

\begin{tabular}{|c|c|c|c|c|c|c|c|c|c|c|c|}
\hline \multirow[t]{2}{*}{ profile } & \multirow{2}{*}{$\begin{array}{c}\text { Depth } \\
\mathrm{Cm} \\
\end{array}$} & \multirow[t]{2}{*}{$\mathrm{pH}$} & $\mathrm{EC}$ & \multicolumn{4}{|c|}{ Soluble Cations me/1 } & \multicolumn{4}{|c|}{ Soluble anion me/l } \\
\hline & & & $\mathrm{dS} / \mathrm{m}$ & $\mathrm{Ca}^{++}$ & $\mathrm{Mg}^{++}$ & $\mathrm{Na}^{+}$ & $\mathrm{K}^{+}$ & $\mathrm{CO}_{3}^{--}$ & $\mathrm{HCO}_{3}^{-}$ & $\mathrm{Cl}^{-}$ & $\mathrm{SO}_{4}^{--}$ \\
\hline \multirow[t]{3}{*}{11} & $0-50$ & 7.46 & 0.53 & 1.44 & 0.96 & 2.40 & 0.48 & 0.00 & 0.96 & 3.17 & 0.68 \\
\hline & $50-100$ & 7.51 & 0.44 & 0.92 & 0.69 & 2.52 & 0.29 & 0.00 & 0.45 & 2.61 & 1.35 \\
\hline & $100-150$ & 7.69 & 0.61 & 1.12 & 0.79 & 3.77 & 0.36 & 0.00 & 0.72 & 4.31 & 1.01 \\
\hline \multirow[t]{3}{*}{12} & $0-50$ & 7.47 & 0.55 & 1.43 & 0.97 & 2.41 & 0.47 & 0.00 & 0.97 & 3.16 & 0.68 \\
\hline & $50-100$ & 7.52 & 0.48 & 0.92 & 0.69 & 2.52 & 0.29 & 0.00 & 0.45 & 2.61 & 1.35 \\
\hline & $100-150$ & 7.69 & 0.68 & 1.12 & 0.79 & 3.77 & 0.36 & 0.00 & 0.72 & 4.31 & 1.01 \\
\hline \multirow[t]{3}{*}{13} & $0-50$ & 7.46 & 0.52 & 1.45 & 0.95 & 2.42 & 0.46 & 0.00 & 0.98 & 3.15 & 0.67 \\
\hline & $50-100$ & 7.53 & 0.46 & 0.92 & 0.69 & 2.52 & 0.29 & 0.00 & 0.45 & 2.61 & 1.35 \\
\hline & $100-150$ & 7.70 & 0.67 & 1.12 & 0.79 & 3.77 & 0.36 & 0.00 & 0.72 & 4.31 & 1.01 \\
\hline \multirow[t]{3}{*}{14} & $0-50$ & 7.48 & 0.59 & 1.44 & 0.97 & 2.40 & 0.47 & 0.00 & 0.95 & 3.18 & 0.68 \\
\hline & $50-100$ & 7.55 & 0.49 & 0.92 & 0.69 & 2.52 & 0.29 & 0.00 & 0.45 & 2.61 & 1.35 \\
\hline & $100-150$ & 7.65 & 0.68 & 1.12 & 0.78 & 3.78 & 0.36 & 0.00 & 0.73 & 4.30 & 1.01 \\
\hline
\end{tabular}


The dominant cation is sodium followed by calcium then magnesium and the least dominant is potassium where as the dominant anion is chloride followed by sulfate then bicarbonate. The soil reaction is slightly alkaline $(7.46-7.7)$.

The fertility status, which is shown in table 3 , show that the organic matter content is ranging from 0.42 and $0.61 \%$. In general, the low value of organic matter is due to the hyperthermic temperature dominating in the study area. The available nitrogen is very low whereas its values equal to $30 \mathrm{mg} / \mathrm{kg}$. The soils are very poor in phosphorus (less than $3.0 \mathrm{mg} / \mathrm{kg}$ ), and also are very poor of potassium content $34.0-80.2 \mathrm{mg} / \mathrm{kg}$.

\section{3-2- SOIL CLASSIFICATION}

\section{3-2-1- SOIL TAXONOMY CLASSIFICATION}

In the light of the relevant soil properties, one order could be distinguished that is belonging to the order Entisols, and one sub order could be distinguished, namely Psamments. At the great group level, only one was distinguished, namely Torripsamments. Moreover, two subgroups are covering the study area namely Typi-Torripsamments and Lithic-Torripsamments,(Fig. 6).

\section{3-2-2- SOIL EVALUATION}

\section{3-2-2-1- LAND CAPABILITY CLASSIFICATION}

The purpose of land capability classification systems is to study and record all data relevant to find the combination of agricultural and conservation measures which would permit the most intensive and appropriate agricultural use of the land without undue danger of soil degradation. The best known one is the Modified Storie Index adopted by UCDAVIS (2008) was applied in the current study to evaluate the land capability of the study area. It is based on the generally accepted forms of land evaluation like, FAO (1981).

The Storie Index is a widely known and accepted method of rating soils for land use and productivity over world. This index had been developed and modified by University of California for generating digitally soil ratings. A modified Storie index is a part of comprehensive software called NASIS (National Soil Information System). In this study the relationships between the values of soils properties and their ratings and the final capability classes adopted by Modified Storie Index, UCDAVIS (2008), have been digitized and put in mathematical equations or calculations. Then the processes and calculations of Modified Storie Index were coded using Visual basic for application (VBA). In general the final capability classes are calculated depending upon the Storie Index Rating.

By applying Storie Index equation, the soils of study area in general are Grade 3 (fair ) with very few exceptional cases that are showing either grade 4 (poor) or grade 5 (nonagricultural soils),( Table 5 and Fig. 7).

The areas that are represented by the soil profiles numbers $3,4,8$ and 10 to 14 , are belonging to the land capability class fair, while the areas that are represented by the soil profiles numbers $5,6,7,9$ are belonging to the land Capability class poor. On the other hand, the areas that are represented by the soil profiles nos. 1 and 2 are belonging to the land capability class nonagricultural as they are very shallow soils.

\section{3-2-2-2- GENERAL LAND SUITABILITY}

The suitability of a given piece of land is its naturally ability to support a specific purpose. 


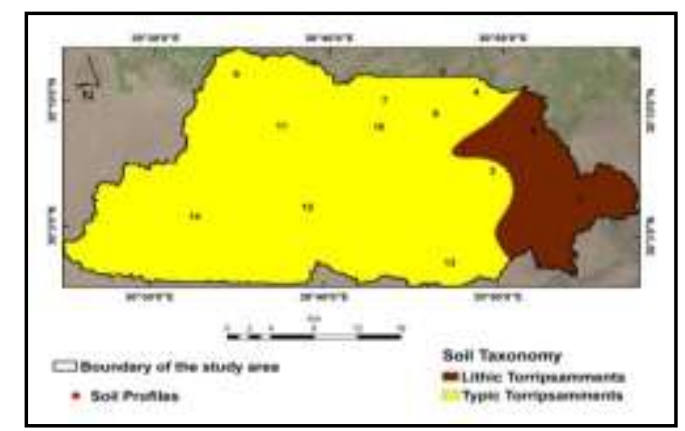

Fig. 6: Taxonomic classification of the study area

Table 5: General land capability classification (Modified Storie Index) of the study area

\begin{tabular}{|l|l|l|l|l|l|l|l|l|l|l|l|}
\hline \multirow{2}{*}{ S.P.N } & \multicolumn{10}{|c|}{ Rate } & \multirow{2}{*}{ Classes } \\
\cline { 2 - 11 } & Depth & Gravel & Slope & pH & SAR & EC & Erosion & Texture & Drainage & Final & \\
\hline 1 & 19 & 83 & 97 & 100 & 78 & 86 & 100 & 60 & 50 & 3 & Grade 5 \\
\hline 2 & 19 & 84 & 100 & 100 & 90 & 86 & 100 & 60 & 50 & 4 & Grade 5 \\
\hline 3 & 93 & 94 & 99 & 100 & 98 & 99 & 100 & 60 & 90 & 45 & Grade 3 \\
\hline 4 & 93 & 94 & 100 & 100 & 95 & 96 & 100 & 60 & 90 & 43 & Grade 3 \\
\hline 5 & 93 & 93 & 99 & 100 & 91 & 90 & 100 & 60 & 90 & 38 & Grade 4 \\
\hline 6 & 93 & 94 & 100 & 100 & 91 & 91 & 100 & 60 & 90 & 39 & Grade 4 \\
\hline 7 & 93 & 94 & 100 & 100 & 92 & 83 & 100 & 60 & 90 & 36 & Grade 4 \\
\hline 8 & 84 & 100 & 98 & 100 & 97 & 99 & 100 & 60 & 90 & 43 & Grade 3 \\
\hline 9 & 93 & 94 & 98 & 100 & 91 & 91 & 100 & 60 & 90 & 38 & Grade 4 \\
\hline 10 & 84 & 100 & 99 & 100 & 97 & 98 & 100 & 60 & 90 & 43 & Grade 3 \\
\hline 11 & 93 & 93 & 99 & 100 & 97 & 98 & 100 & 60 & 85 & 41 & Grade 3 \\
\hline 12 & 93 & 93 & 96 & 100 & 97 & 98 & 100 & 60 & 85 & 40 & Grade 3 \\
\hline 13 & 93 & 93 & 98 & 100 & 97 & 98 & 100 & 60 & 85 & 41 & Grade 3 \\
\hline 14 & 93 & 93 & 97 & 100 & 97 & 98 & 100 & 60 & 85 & 41 & Grade 3 \\
\hline
\end{tabular}

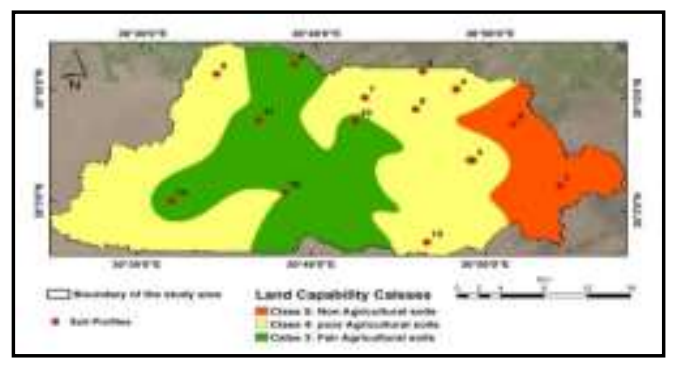

Fig. 7: land Capability classification of the study area.

This is strongly related to the land qualities which are derived from land characteristics such as slope, soil texture......etc. The current study used Land Use Suitability Evaluation Tool (LUSET) software to assess the soil suitability for specific types of crops. In this respect, 15 different crops were classified to determine the soil suitability for each crop as discussed hereafter Yen B.T., et.al (2006). The processes and calculations of LUSET program were coded by using Visual Basic for application. However, LUSET comprises three components; the main program file, crop requirement information file, and land quality information file. On the other hand, there are four methods for computing the overall suitability (maximum, minimum, 
average, or exponent) and types of overall suitability (rated by 1 to 100 or rated by S1, S2, S3, and $\mathrm{N}$ ). The requirements of the most commonly grown crops provided are recorded in this program.

LUSET was used to evaluate the soils of the study area using the exponent equation. Accordingly, the soil suitability showed that major suitability classes have been noted, moderately suitable (S2) for all the selected crops with some exceptional cases that may be highly suitable (S1) or (S3) that are marginally suitable for all selected crops, (Table 6 and 7) . The areas that are represented by the soil profiles numbers.1 and 2 are moderately suitable for the Cucumber, Watermelon, Onion, Pepper green, Sunflower, Potato, Ground nut, Barley, Wheat, Sorghum, Maize, Olive, Sesame and Mango. On the other hand, they are marginally suitable for Pear. The areas that are represented by the soil profiles nos. 3 to 10 are moderately suitable for the Cucumber, Watermelon, Onion, and Pepper green, Sunflower, Potato, Groundnut, Pear, Wheat, Maize, Olive, Sesame and Mango. On contrary, they are highly suitable for Barley and Sorghum. Except areas that are represented by the soil profile no.9 are also highly suitable for Onion, Sunflower, Wheat and Olive.

Table 6: Land Use Suitability Evaluation Tool (LUSET) of the study area, (Rated by 1 to 100)

\begin{tabular}{|l|c|l|l|l|l|l|l|l|l|l|l|l|l|l|l|}
\hline S.P.N & C & Wa & On & Pe & Su & Po & G & Pr & B & Wh & So & Mz & Ol & Se & Mo \\
\hline $\mathbf{1}$ & $\mathbf{7 2}$ & $\mathbf{7 1}$ & $\mathbf{7 7}$ & $\mathbf{6 5}$ & $\mathbf{7 2}$ & $\mathbf{6 4}$ & $\mathbf{6 4}$ & $\mathbf{5 7}$ & $\mathbf{8 0}$ & $\mathbf{8 3}$ & $\mathbf{8 3}$ & $\mathbf{7 4}$ & $\mathbf{7 3}$ & $\mathbf{6 2}$ & $\mathbf{7 3}$ \\
\hline $\mathbf{2}$ & $\mathbf{7 0}$ & $\mathbf{7 4}$ & $\mathbf{7 3}$ & $\mathbf{6 5}$ & $\mathbf{7 4}$ & $\mathbf{6 5}$ & $\mathbf{7 1}$ & $\mathbf{5 5}$ & $\mathbf{8 0}$ & $\mathbf{8 3}$ & $\mathbf{8 3}$ & $\mathbf{7 3}$ & $\mathbf{7 5}$ & $\mathbf{6 1}$ & $\mathbf{6 7}$ \\
\hline $\mathbf{3}$ & $\mathbf{7 2}$ & $\mathbf{7 6}$ & $\mathbf{7 5}$ & $\mathbf{6 6}$ & $\mathbf{7 6}$ & $\mathbf{6 7}$ & $\mathbf{7 5}$ & $\mathbf{6 7}$ & $\mathbf{8 8}$ & $\mathbf{7 9}$ & $\mathbf{8 9}$ & $\mathbf{7 0}$ & $\mathbf{8 5}$ & $\mathbf{6 5}$ & $\mathbf{6 8}$ \\
\hline $\mathbf{4}$ & $\mathbf{7 5}$ & $\mathbf{7 8}$ & $\mathbf{7 9}$ & $\mathbf{6 8}$ & $\mathbf{7 9}$ & $\mathbf{7 0}$ & $\mathbf{7 7}$ & $\mathbf{6 9}$ & $\mathbf{8 9}$ & $\mathbf{7 9}$ & $\mathbf{8 8}$ & $\mathbf{7 3}$ & $\mathbf{8 3}$ & $\mathbf{7 1}$ & $\mathbf{7 1}$ \\
\hline $\mathbf{5}$ & $\mathbf{7 2}$ & $\mathbf{7 6}$ & $\mathbf{7 6}$ & $\mathbf{6 6}$ & $\mathbf{7 6}$ & $\mathbf{6 7}$ & $\mathbf{7 4}$ & $\mathbf{6 7}$ & $\mathbf{8 8}$ & $\mathbf{7 9}$ & $\mathbf{8 8}$ & $\mathbf{7 3}$ & $\mathbf{7 6}$ & $\mathbf{6 5}$ & $\mathbf{7 0}$ \\
\hline $\mathbf{6}$ & $\mathbf{7 5}$ & $\mathbf{7 9}$ & $\mathbf{7 8}$ & $\mathbf{6 8}$ & $\mathbf{7 9}$ & $\mathbf{7 0}$ & $\mathbf{7 7}$ & $\mathbf{6 9}$ & $\mathbf{8 8}$ & $\mathbf{7 9}$ & $\mathbf{8 8}$ & $\mathbf{7 3}$ & $\mathbf{8 2}$ & $\mathbf{7 1}$ & $\mathbf{7 1}$ \\
\hline $\mathbf{7}$ & $\mathbf{7 4}$ & $\mathbf{7 8}$ & $\mathbf{7 3}$ & $\mathbf{6 6}$ & $\mathbf{7 8}$ & $\mathbf{6 8}$ & $\mathbf{7 7}$ & $\mathbf{6 6}$ & $\mathbf{8 8}$ & $\mathbf{7 6}$ & $\mathbf{8 8}$ & $\mathbf{7 3}$ & $\mathbf{7 6}$ & $\mathbf{7 0}$ & $\mathbf{7 1}$ \\
\hline $\mathbf{8}$ & $\mathbf{7 3}$ & $\mathbf{7 7}$ & $\mathbf{7 9}$ & $\mathbf{6 8}$ & $\mathbf{7 9}$ & $\mathbf{6 8}$ & $\mathbf{7 8}$ & $\mathbf{6 8}$ & $\mathbf{8 8}$ & $\mathbf{7 9}$ & $\mathbf{8 8}$ & $\mathbf{7 3}$ & $\mathbf{8 1}$ & $\mathbf{6 7}$ & $\mathbf{7 1}$ \\
\hline $\mathbf{9}$ & $\mathbf{7 9}$ & $\mathbf{8 2}$ & $\mathbf{8 6}$ & $\mathbf{7 9}$ & $\mathbf{8 6}$ & $\mathbf{7 3}$ & $\mathbf{8 4}$ & $\mathbf{7 4}$ & $\mathbf{8 8}$ & $\mathbf{8 9}$ & $\mathbf{8 8}$ & $\mathbf{7 9}$ & $\mathbf{8 6}$ & $\mathbf{8 1}$ & $\mathbf{7 8}$ \\
\hline $\mathbf{1 0}$ & $\mathbf{7 5}$ & $\mathbf{7 9}$ & $\mathbf{7 9}$ & $\mathbf{6 8}$ & $\mathbf{7 9}$ & $\mathbf{6 9}$ & $\mathbf{7 8}$ & $\mathbf{6 8}$ & $\mathbf{8 8}$ & $\mathbf{7 9}$ & $\mathbf{8 8}$ & $\mathbf{7 3}$ & $\mathbf{8 3}$ & $\mathbf{6 7}$ & $\mathbf{7 1}$ \\
\hline $\mathbf{1 1}$ & $\mathbf{7 4}$ & $\mathbf{7 8}$ & $\mathbf{7 9}$ & $\mathbf{6 8}$ & $\mathbf{7 8}$ & $\mathbf{6 7}$ & $\mathbf{7 7}$ & $\mathbf{6 7}$ & $\mathbf{8 8}$ & $\mathbf{7 9}$ & $\mathbf{8 9}$ & $\mathbf{7 3}$ & $\mathbf{7 6}$ & $\mathbf{6 6}$ & $\mathbf{7 1}$ \\
\hline $\mathbf{1 2}$ & $\mathbf{6 5}$ & $\mathbf{6 9}$ & $\mathbf{7 9}$ & $\mathbf{6 8}$ & $\mathbf{7 8}$ & $\mathbf{6 0}$ & $\mathbf{7 2}$ & $\mathbf{6 4}$ & $\mathbf{8 9}$ & $\mathbf{7 9}$ & $\mathbf{8 8}$ & $\mathbf{7 1}$ & $\mathbf{7 6}$ & $\mathbf{6 6}$ & $\mathbf{6 7}$ \\
\hline $\mathbf{1 3}$ & $\mathbf{7 3}$ & $\mathbf{7 7}$ & $\mathbf{7 9}$ & $\mathbf{6 8}$ & $\mathbf{7 8}$ & $\mathbf{6 7}$ & $\mathbf{7 7}$ & $\mathbf{6 8}$ & $\mathbf{8 8}$ & $\mathbf{7 9}$ & $\mathbf{8 8}$ & $\mathbf{7 3}$ & $\mathbf{7 6}$ & $\mathbf{6 6}$ & $\mathbf{7 1}$ \\
\hline $\mathbf{1 4}$ & $\mathbf{7 1}$ & $\mathbf{7 5}$ & $\mathbf{7 9}$ & $\mathbf{6 8}$ & $\mathbf{7 8}$ & $\mathbf{6 4}$ & $\mathbf{7 6}$ & $\mathbf{6 7}$ & $\mathbf{8 8}$ & $\mathbf{7 9}$ & $\mathbf{8 8}$ & $\mathbf{7 3}$ & $\mathbf{7 4}$ & $\mathbf{6 7}$ & $\mathbf{7 1}$ \\
\hline
\end{tabular}

Table 7: Land Use Suitability Evaluation Tool (LUSET) of the study area (Rated by S1, S2, S3, and N)

\begin{tabular}{|c|c|c|c|c|c|c|c|c|c|c|c|c|c|c|c|}
\hline S.P.N & C & Wa & On & Pe & Su & Po & G & Pr & B & Wh & So & $\mathbf{M z}$ & Ol & Se & Mo \\
\hline 1 & S2 & S2 & S2 & S2 & S2 & S2 & S2 & S3 & S2 & S2 & S2 & S2 & S2 & S2 & S2 \\
\hline 2 & S2 & S2 & S2 & S2 & S2 & S2 & S2 & S3 & S2 & S2 & S2 & S2 & S2 & S2 & S2 \\
\hline 3 & S2 & S2 & S2 & S2 & S2 & S2 & S2 & S2 & S1 & S2 & S1 & S2 & S2 & S2 & S2 \\
\hline 4 & S2 & S2 & S2 & S2 & S2 & S2 & S2 & S2 & S1 & S2 & S1 & S2 & S2 & S2 & S2 \\
\hline 5 & S2 & S2 & S2 & S2 & S2 & S2 & S2 & S2 & S1 & S2 & S1 & S2 & S2 & S2 & S2 \\
\hline 6 & S2 & S2 & S2 & S2 & S2 & S2 & S2 & S2 & S1 & S2 & S1 & S2 & S2 & S2 & S2 \\
\hline 7 & S2 & S2 & S2 & S2 & S2 & S2 & S2 & S2 & S1 & S2 & S1 & S2 & S2 & S2 & S2 \\
\hline 8 & S2 & S2 & S2 & S2 & S2 & S2 & S2 & S2 & S1 & S2 & S1 & S2 & S2 & S2 & S2 \\
\hline 9 & S2 & S2 & S1 & S2 & S1 & S2 & S2 & S2 & S1 & S1 & S1 & S2 & S1 & S2 & S2 \\
\hline 10 & S2 & S2 & S2 & S2 & S2 & S2 & S2 & S2 & S1 & S2 & S1 & S2 & S2 & S2 & S2 \\
\hline 11 & S2 & S2 & S2 & S2 & S2 & S2 & S2 & S2 & S1 & S2 & S1 & S2 & S2 & S2 & S2 \\
\hline 12 & S2 & S2 & S2 & S2 & S2 & S3 & S2 & S2 & S1 & S2 & S1 & S2 & S2 & S2 & S2 \\
\hline 13 & S2 & S2 & S2 & S2 & S2 & S2 & S2 & S2 & S1 & S2 & S1 & S2 & S2 & S2 & S2 \\
\hline 14 & S2 & S2 & S2 & S2 & S2 & S2 & S2 & S2 & S1 & S2 & S1 & S2 & S2 & S2 & S2 \\
\hline
\end{tabular}




\section{REFERENCES}

1. Aldahaa A. A. A. (2012). Potential land use in the new reclamation areas at wadi F.1-R avan denrescion and its envirnns, El-Fayum governorate, Egypt. Ph. D. Thesis, Agri. Sci. Fac., Cairo Univ. Cairo, Egypt.

2. Anderson R..I.. F. F. Hardv. .I.T. Roach. and R.F.. Witmer (2001) A I and I Ise and I and Cover Clacsification Svstem for ITse with Remote Sensor Data Genlooical Survev Profescinnal Paner 964 A revision of the land use classification system as presented in U.S. Geological Survey Circular 671.

3. Rashour. I.I. and A.H. Saveoh. 2007 Methods of Analvsis for Snils of Arid and SemiArid Region, American University of Beirut, Lebanon. FAO, Rome.

4. Reek. K.I. 1978. Land evaluation for agricultural development. ILRI Publication 23. ILRI, Wageningen.

5. De la Rosa. D.. Mnrenn. I. A.. Garcia. I..V. \& Almorza. .I. (1992). MicroI F.IS A micrncomnuter-hased Mediterranean land evaluation information system. Soil Use \& Management, 8: 89-96.

6. Egyptian Meteorological Authority (2006). Climate Atlas of Egypt, Cairo, Egypt.

7. F.l Ahd F. A. F. (2005). The oenlooical imnact on the water hearino formatinns in the area southwest Nile Delta, Egypt. Ph. D. Thesis Doctor, Minufiya University, Minufiya, Egypt.

8. Fmheroer. I. (1955 ) A frime du Nord-Oıest In Plant ecology: reviews of research (ed. UNESCO), pp. 219-249. Paris, France: UNESCO.

9. FA (1981). A framexyork for land evalıation Soils Bulletin 32. Food and Agriculture Organization of the United Nations, Rome, Italy.

10. FAO (1985) Guidelines- land evalıation for irrigated agriculture. Soils Bulletin 55, Rome, Italy: FAO. 231 p. S590 .F68 no. 55 Mann.

11. FAO (2006). Guideline for soil description, Fourth Edition. Rome.

12. Olson, G.W. (1974). Land classifications. Search: Agriculture 4, 1-34.

13. Olson F W (1981). Soils and the Environment. New York: Chapman \& Hall. 178 pp. S592.14 O52 Mann

14. Piper C.J. (1950). Soil and Plant Analysis. University of Adelaide, Adelaide

15. Rossiter D.G. (1996). A Theoretical Framework for Land Evaluation. Geoderma, 72: 165 202. 16. Snil Survev Staff (mon). Soil Survey Laboratory Methods Manual. Soil Survey

17. Snil Survev Staff. (2014). Kevs to Sni1 Taxonomy, 11th ed. USDA-Natural Resources Conservation Services, Washington, DC.

18. Storie R (1922). An index for rating the aoricultural values of soils. Bulletin 556. Berkeley: California Agricultural Experiment Station.

19. Sve C (1980) I and Characteristics and Qualities and Methods of Rating Them. ITC PostGraduate Lecture Note. Ghent, Belgium.

20. Svs. $\boldsymbol{C}$. and $\mathbf{W}$. Verheve. (1978). An attemnt to the evaluation of nhvsical land characteristics for irrigation accordino to the FAO framework for land evaluation. ITC Post-Graduate Lecture Note. Ghent, Belgium.

21. Svs $\boldsymbol{C}$. F. Van Ranst and .I. Mehaveve (1991). I and evaluation Part I and II-cron renuirement Reloium General Administration for Development Cooperation. Agricultural Publications No. 7.

22. ITCDAVIS (2008). A Reviced Storie Index for I Tse with Dioital Soils Information. University of California Division of Agriculture and natural Resources. 
23. Van Dienen. C A . Van Keulen. H. Wolf. I. \& Rerkhout . I. A A 1991. I and evaluation. from intuition to muantification. In: Advances In Soil Science (ed. B.A. Stewart). Springer, New York, 139-204 p.

24. Vink A.P.A., (1983) Landscape Ecology and land use. Longman, London.

25. Yen B.T., K.S. Pheng and C.T. Hoanh (2006). Land Use Suitability Evaluation Tool (LUSET), GIS-IP Laboratory, International Rice Research Institute, Dapo, Box 7777, Metro Manila, Philippines 